\title{
Surgical Treatment of Glioblastoma Multiforme Localized in the Motor Area of the Brain Using the Technique of Cortical Electrostimulation
}

\section{Motor Kortekse Yerleşmiş Glioblastome Multiforme Cerrabisinde Kortikal Elektrostimülasyon Tekniğinin Yeri}

Vojislav BOGOSAVLJEVIC, Goran TASIC, Branislav NESTOROVIC, Vladimir JOVANOVIC, Miodrag RAKIC, Miroslav SAMARDZIC

Clinical Centre of Serbia, Institute for Neurosurgery, Belgrade, Serbia, Yugoslavia

Correspondence address: Vojislav BOGOSAVLJEVIC / E-mail: neurobog@beotel.rs

\begin{abstract}
AIM: Glioblastoma multiforme in the motor area is the surgical challenge because of the need for more radical resection in order to extend the life of the patient, and the risk that radicalism could lead to additional neurological deficit.

MATERIAL and METHODS: We present series of 26 patients with glioblastoma multiforme localized in and around the motor area, who were hospitalized from October 2004 to February 2009. During all operations, we conducted electrostimulation display area of the brain, to the anatomical location of M1 segment of the motor cortex.

RESULTS: Distance of the central sulcus in relation to the coronary suture, measured by magnetic resonance imaging (MRI) was $18.38 \mathrm{~mm} \pm$ $9.564 \mathrm{~mm}$. The volume of electricity required for a motor response was mean $8.79 \pm 1.484 \mathrm{~mA}$, with increasing distance from the coronary suture the amperage required to explicit motor responses decreased. The difference $(\mathrm{mm})$ between the distance from the coronary suture measured using MRI and distances measured electrostimulation smaller and power consumption was less $(F=13.285, p<0.01)$.

CONCLUSION: The method of cortical cerebral cortex electrostimulation is simple and safe method and a binding protocol to the patient safe operation glioblastoma multiforme localized in the motor area of the brain.
\end{abstract}

KEYWORDS: Brain, Electrostimulation, Glioblastoma multiforme, Motor cortex

öz

AMAÇ: Bir yandan radikal cerrahi rezeksiyonla sağlanan artmış yaşam beklentisi, öte yandan bu bölge radikal cerrahisinin yol açacağı nörolojik defisit nedeniyle motor kortekse yerleşmiş glioblastome multiforme olguları cerrahi olarak güç vakalardır.

YÖNTEM ve GEREÇLER: Ekim 2004 ile Şubat 2009 arasında motor kortekse veya yakınına yerleşmiş 26 glioblastome multiforme olgusu incelenmiştir. Yapılan tüm ameliyatlarda motor korteksin M1 segmentinin anatomik lokalizasyonu elektrostimülasyon ile ortaya konmuştur.

BULGULAR: Manyetik rezonans görüntülemesine göre koronal sütür ile santral sulkus arasındaki uzaklık ortalama $18.38 \mathrm{~mm} \pm 9.564 \mathrm{~mm}$. bulundu. Motor cevabı oluşturmak için gerekli olan akımın ortalaması $8.79 \pm 1.484 \mathrm{~mA}$ bulundu. Koronal sütüre olan uzaklık arttıkça ortaya çıkan motor cevap azaldı. Manyetik rezonans görüntülemesine göre ve elektrostimülasyona göre yapılan ölçümlerin (mm) farklılı̆ı analiz edildiğinde; uzaklık elektrostimülasyonda daha azdı $(F=13.285, \mathrm{p}<0.01)$.

SONUÇ: Motor alana yerleşmiş glioblastome multiforme olgularında serebral kortikal elektrostimülasyon basit ve güvenilir bir yöntemdir.

ANAHTAR SÖZCÜKLER: Beyin, Elektrostimülasyon, Glioblastoma multiforme, Motor korteks

\section{INTRODUCTION}

Malignant gliomas cause a total of $2.5 \%$ of cancer deaths per year and are the third cause of death from cancer at the age of 15 to 34 years of age $(13,22)$. Glioblastoma multiforme are most malignant form of primary brain tumors in adults, predominantly localized in the hemisphere, in $24 \%$ were localized in and directly around the motor area of the brain $(14,28)$. Neurosurgeons, brain tumors consider as active lesions for which they need to find a solution, because the smaller the rest of tumor tissue after surgical resection, the longer period of survival $(26,23)$. Therefore it is necessary to know the natural course of brain tumors in their initial, intermediary and terminal stage (30). Despite the maximum radical surgical resection and additional oncological protocols use combination of radio and chemotherapy, overall survival for patient with glioblastoma multiforme is between one and twoyears $(17,15)$.The functions 
of human cortex, despite the anatomical boundaries are organizationally related and surgical resection can basically considered a breach of Preoperative and intraoperative brain mapping, separating the normal from the abnormal function and allows resection of lesions that previously could not even imagine (8). Current studies recommend standard use of intraoperative electrical stimulation of the brain during operations in eloquent brain zone, a method that improves postoperative functional outcome $(5,4,16,31)$. Direct cortical electrostimulation was safe, accurate and easy to perform method for identification of eloquent cortical and subcortical field $(2,18,7)$.

\section{MATERIAL and METHODS}

Our study included a total of 26 patients with supratentorial glioblastoma multiforme localized in and around the motor area in front of the central sulcus, who were hospitalized at the Institute of Neurosurgery, Clinical Center of Serbia in Belgrade from October 2004 to February 2009. Assessment of pre and post operative status of the patients was validated scale Karnofski index. From the study we excluded patients with recurrent tumors and patients whose Karnofski index at admission was less than 70. In order to achieve a clear preoperative orientation, especially in the present cases, infiltrative tumor growth, with no visible boundaries to the surrounding brain tumors, we performed to measure the distance of the central sulcus (the longest in the high parietal sulcus sections) in relation to the coronary suture on MRI images, based on diagnosed and planned operations. All patients were operated under general anesthesia using the general intravenous anesthesia, without the addition of volatile anesthetics. For the induction of anesthesia in the bolus propofol $(1-2 \mathrm{mg} / \mathrm{kg})$ and fentanyl $(5-10 \mu \mathrm{g} / \mathrm{kg})$ were used. Anesthesia was maintained with continuous administration of propofol $(75-125 \mu \mathrm{g} / \mathrm{kg})$. Intraoperative analgesia was achieved by remifentanil $(0.25 \mathrm{mg} / \mathrm{kg} / \mathrm{min})$. Neuromuscular blockers were used only for intubation (rocuronium from 0.3 to $0.4 \mathrm{mg} / \mathrm{kg}$ or mivacurium $0.2 \mathrm{mg} / \mathrm{kg}$ ) but not during the surgery (neuromuscular blockade was effective only 15-25 minutes during intubation). Prophylactically every patient's was provided by preoperative peroral antibiotic ( $2 \mathrm{~g}$ Nilacef to $12 \mathrm{pm}$ ), dexamethasone in a single dose of $8 \mathrm{mg}$ iv in 6 hours and anticonvulsant therapy Mazepin 3x200mg During all operations electrostimulation was conducted on display area of the brain to reach the anatomical location of $\mathrm{M} 1$ segment of the motor cortex (Figure 1). For electrical stimulation of the cortex were used 3-contact strip electrodes (AD-Tech ${ }^{\circledast}$ strip electrodes, AD Tecnica, WI, USA). Upon identifying the motor fields the distance from the coronary suture was measured and performed by comparison with the values obtained from the preoperative measurement of the distance of the central sulcus of the coronary suture on the MRI image. The data were processed by computer aided SPSS 12.0 software package.

\section{RESULTS}

Histopathologic analysis confirmed the existence of glioblastoma multiforme tumors forms in 26 cases. The average age of patients with glioblastoma multiforme was $55.38 \pm 14.020$ years. In all cases the diagnosis of intracranial expansive lesion located in the region of the central sulcus of the brain was made by recording the nuclear magnetic resonances imaging (MRI). In $42.3 \%$ (11) findings of the lesions were localized in the left supratentorial hemisphere, and $57.7 \%$ (15) in the right supratentorial hemisphere. In order to achieve a clear preoperative orientation, especially in the present cases, infiltrative tumor growth, with no visible boundaries to the surrounding brain tumors, we performed to measure the distance of the central sulcus (the longest in the high parietal sulcus sections) in relation to the coronary suture on MRI

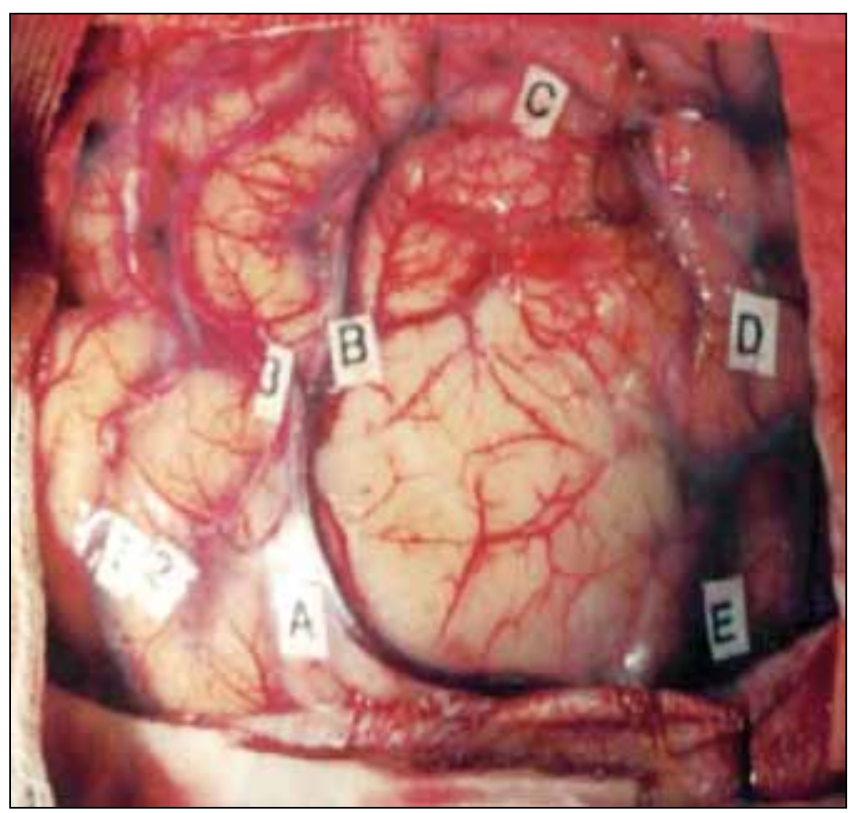

Figure 1: Identification of cerebral motor cortex for direct electrostimulation.

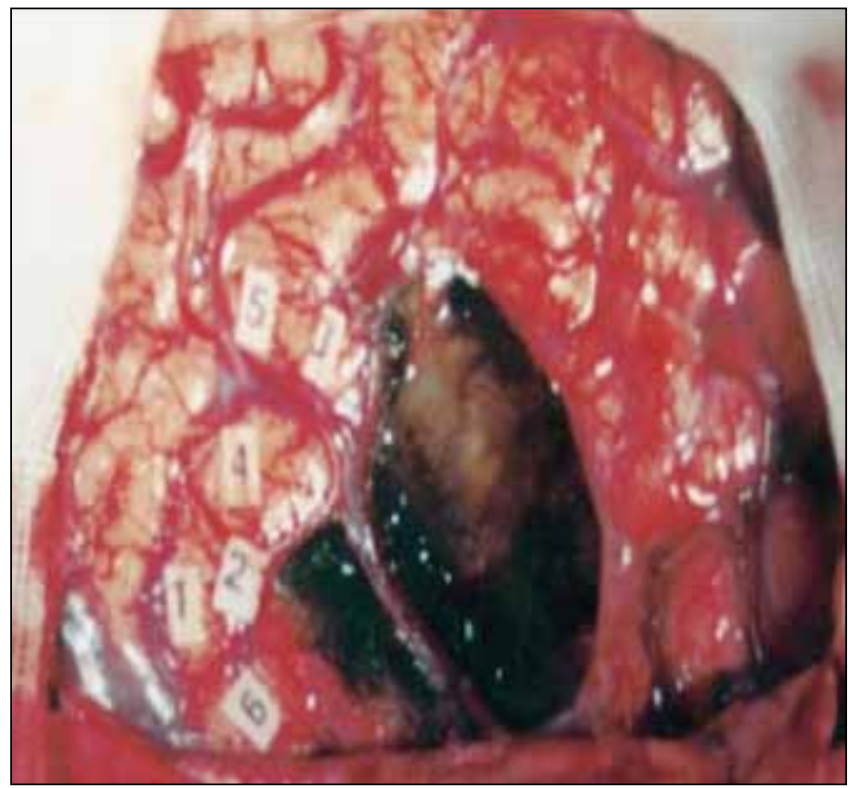

Figure 2: Radical operation with intact cerebral motor cortex. 
images, based on diagnosed and planned operations. The average distance of the central sulcus in relation to the coronary suture was $18.38 \mathrm{~mm} \pm 9.564 \mathrm{~mm}$; minimum distance amounted to $7 \mathrm{~mm}$ and a maximum of $42 \mathrm{~mm}$. (Table I) All patients were operated (26) under general anesthesia, and during all operations we conducted electrostimulation display area of the brain for anatomical location of $\mathrm{M} 1$ segment of the motor cortex (Figure 2). The average value of electric current intensity needed to obtain motor responses was 8.79 $\pm 1.484 \mathrm{~mA}$ (min. $6 \mathrm{~mA}$, max. $12 \mathrm{~mA}$ ). Longer distance from the coronary suture imply decreased strength of current intensity required to explicit motor responses $(r=-0.574, p<0.01)$ Based on these results mathematical regression model is proposed assuming the necessary electric current needed to obtain motor responses during ES M1 field. The proposed regression model showed an absolute statistical reliability $(F=29.030, p<0.01)$ (Figure 3 ).

The regression model is: Current strength $=10.473$ to $0.087 \mathrm{x}$ distance from the coronary suture.

Analyzed was the variable representing the difference in millimeters between the distance of the central sulcus of the coronary suture measured using MRI and distance M1 zone measured from the coronary suture electrostimulation (ES) (Figure 4).

Calculated correlation coefficient is: $r=-0.438, p<0.01$.
The difference $(\mathrm{mm})$ between the distance from the coronary suture measured using MRI and distances measured electrostimulation smaller and power consumption was less $(F=13.285, p<0.01)$.

Regression model is: Rated current $=9.931$ to $0.166 \times$ difference radiographic / electrograph. tool in $\mathrm{mm}(\mathrm{F}=13.285, \mathrm{p}<0.01)$.

The average strength of electric current needed to explicit motor responses in patients suffering from glioblastoma multiforme was $8.115 \pm 1.479 \mathrm{~mA}$. Statistical analysis showed a statistically significant $(p<0.05)$ lower amperage required for the identification of motor areas of tumors where the degree of surgical resection was a subtotal to the level of reduction $(9-34.7 \%)-8.273 \pm 1.162 \mathrm{~mA}$ compared the radical operation (17 - 65.3\%) - 9.079 $\pm 1.549 \mathrm{~mA}$ (Table II). Single view in relation to the histological group of tumors, show a numerical increase of Karnofski index $(\mathrm{Cl})$ after surgery compared to the situation before surgery. The mean value of $\mathrm{KI}$ before surgery for glioblastoma multiforme was $75.38 \pm$ 8.593 and postoperative $79.23 \pm 8.910$ (Table III).

\section{DISCUSSION}

Surgery of lesions localized in the motor cortex is a challenging part because of the accompanying risk of de novo occurrence of motor deficit. Intrinsic tumors may affect cortical and subcortical structures, with no signs of functional deterioration (Figure 4). On the other hand a clear presentation

Table I: Distance to the Central Sulcus of the Coronary Suture / MRI

\begin{tabular}{|c|c|c|c|c|c|c|}
\hline N & Arithmetic Mean & Median & Min & Max & Range & Std. Deviation \\
\hline 61 & 18.38 & 15.00 & 7 & 42 & 35 & 9.564 \\
\hline
\end{tabular}

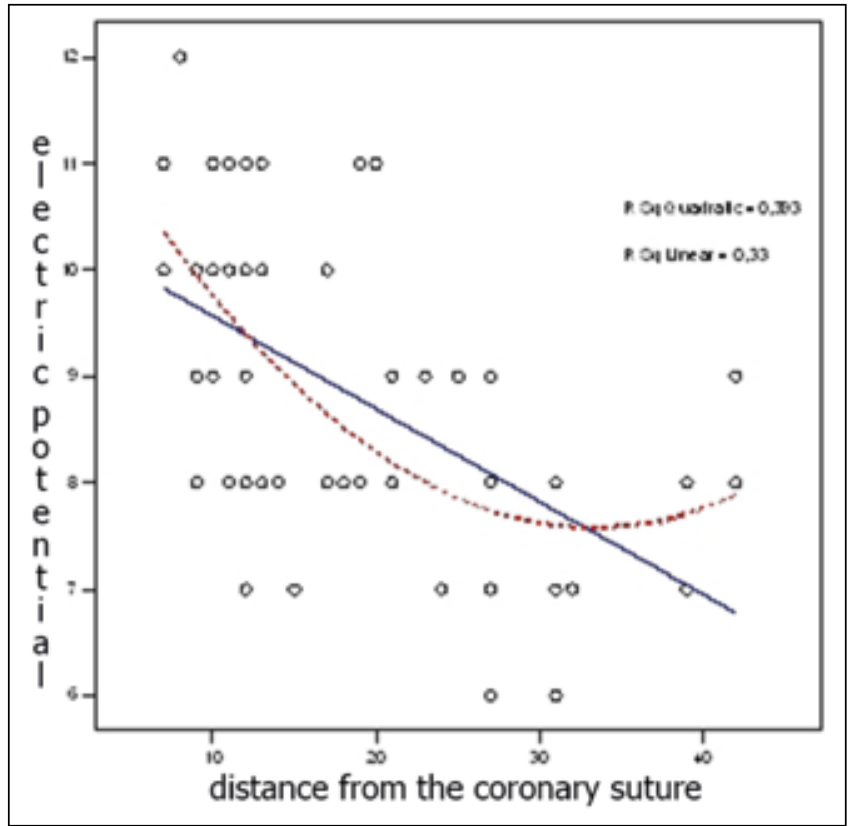

Figure 3: The relation of electric potential and the distance the motor zone of the coronary suture.

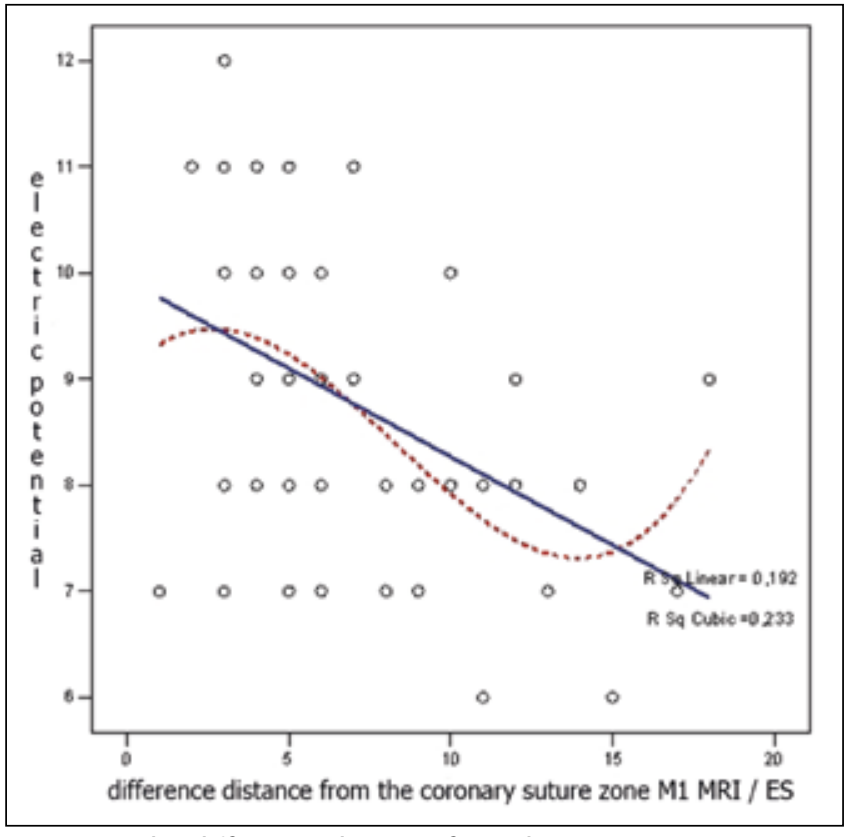

Figure 4: The difference distance from the coronary suture zone M1 MRI / ES. 
Table II: ES - Current in Dependence of HP Findings and Extent of Surgical Resection

\begin{tabular}{|c|c|c|c|c|c|c|c|c|}
\hline & & \multicolumn{6}{|c|}{ Amperage } & \multirow[b]{2}{*}{ Results } \\
\hline & & $\mathbf{N}$ & $\begin{array}{c}\text { Arithmetic } \\
\text { Mean }\end{array}$ & $\begin{array}{c}\text { Std. } \\
\text { Deviation }\end{array}$ & Median & Min & $\operatorname{Max}$ & \\
\hline HP exam & glioblastom & 26 & 8.115 & 1.479 & 8.00 & 6 & 12 & \\
\hline Degree of surgical resection & $\begin{array}{l}\text { subtotal } \\
\text { radical }\end{array}$ & $\begin{array}{c}9 \\
17\end{array}$ & $\begin{array}{l}8.273 \\
9.079\end{array}$ & $\begin{array}{l}1.162 \\
1.549\end{array}$ & $\begin{array}{l}8.00 \\
9.00\end{array}$ & $\begin{array}{l}7 \\
6\end{array}$ & $\begin{array}{l}11 \\
12\end{array}$ & $Z=-2.278 ; p<0.05$ \\
\hline
\end{tabular}

Table III: The Value of the Index Karnofski Pre-Post Operative

\begin{tabular}{|l|l|l|c|c|c|c|c|c|}
\hline HP Exam & & N & Arithmetic Mean & Median & Min & Max & Range & Std. Deviation \\
\hline \multirow{2}{*}{ glioblastoma } & Karnofski index - pre op & 26 & 75.38 & 70,00 & 60 & 90 & 30 & 8.593 \\
& Karnofski index - post op & 26 & 79.23 & 80,00 & 60 & 90 & 30 & 8.910
\end{tabular}

of the vast area of the tumor in a patient without neurological deficits present before surgery may not be a guarantee that the tumor can be removed radically without the possibility of subsequent motor deficit (25).Group of authors is of opinion that the length of survival after surgery are directly dependent on the degree of resection as the low grade and high grade gliomas in the brain, and if the resection include the supplementary motor field can be the full Iniencephaly (2). Electrical stimulation of the cortex in infiltrating glioma of the brain localized in the motor cortex prevents damage to functionally important parts of the cortex and allows radicalism operations $(1,21)$. Skriboll emphasizes that it is difficult to determine whether additional postoperative neurological deficits is caused by intratumoral localization of motor fibers or due to manipulation surgical zone near the motor or both reasons (27). Tumor invasion of functional cortex, the compression effect and functional organization of the cortex raises the need for finding the shortest safe access to the tumor in order to achieve a higher degree of radicalism. Sir Victor Horsley identified centres for arms and legs by performing an experimental electrical stimulation of the cortex of monkeys $(11,12)$. Fritisch and Hitzing $(1870)$ conducted the first controlled electrical stimulation of cerebral cortex- the front half of the supratentorial hemisphere of dog, connecting a source of direct galvanic current with a bipolar electrode. Direct cortical stimulation DC galvanic current human cerebral cortex gaining sensory and motor response was made by Robert Bartholow (1874), placing wires in the pulp chamber abscess localized in the left convexity supratentorial hemisphere and watched the observed contraction of the right shoulder and leg (33). Until the present time the primary method experienced modifications, including the current electrostimulation waking patients, conceived by Gruenbaum-and Cushing and confirmed by the Penfield-in the form of recommendations for a safe surgical approach to lesions localized in eloquent areas of the brain $(3,10,20)$. Yoshiura et al identified increased activity in contralateral motor area on $\mathrm{fMRI}$ in patients with brain tumor in the motor zone (34). Schiffbauer and Thiel models emphasize the dynamic functional reorganization in the surrounding peritumour brain, creating compensatory motor fields, which explains the absence of motor deficits in tumors localized in the motor area of cerebral cortex, and also the emergence of the deficit immediately after operation, with a tendency to complete recovery within 3 months postoperatively (25, 32). Suess analyzed 225 surgically treated tumors out of which 121 in direct contact, and 134 over the primary cortex showing a correlation between the use of electrocortical stimulation procedures in order to identify the primary cortex and the degree of surgical radicality. In 11 cases patients had delayed motor deficit in the period of 8 hours to 3 days after surgery, which completely recovered within three months (29). Duffau et al. indicate the effect of glioma infiltration on local brain function in three patients who underwent reoperation within 12 to 24 months after the first surgery (8). All three patients had neurological deficits preoperatively, operated from low grade glioma localized in functionally important brain motor area. For each operation, the procedure used electrical stimulation of the cortex and functional mapping - identification of motor areas of the brain. Since the tumors were localized in the sensorimotor cortex in all three cases underwent subtotal resection. All three patients were reoperated 12-24 months later, re-electro cortex and functional mapping of motor areas. In all three cases in the repeated surgery was performed a radical resection without additional neurological deficits. Duffau recommends the standard use of intraoperative electrical stimulation of the brain during operations in eloquent areas of the brain as a method which improves postoperative functional outcome $(4,5,8,6,16,31)$. Direct cortical electrostimulation is safe, accurate and easy to perform method for identification of eloquent cortical and subcortical field $(2,7,18)$. Functional neural tissue can be detected inside the tumor which causes a limited surgical resection $(19,27)$. Modification in the spatial organization and direction of tumor growth can be caused by previous surgery and tumor it self can cause functional peritumoural reorganization of motor cortex with the absence of neurological deficit, although part of the eloquent area located within the boundaries of the tumor and / or induce compensatory function of other ipsilateral regions responsible for the same function $(5,6,7,19)$. 


\section{CONCLUSION}

Direct electrostimulation of cerebral cortex is a reliable method for identification of motor areas of the brain, and a requirement for additional prevention - iatrogenic neurologic deficit. Schiffbauer and colleagues, comparing the difference in distance between the motor areas on the basis of MRI findings, the average distance of the motor areas of the coronary suture $-12.5 \mathrm{~mm}$, and distance the motor areas of the coronary suture identification ES - $19 \mathrm{~mm}$, indicate that the difference in distance motor offsets the MRI findings and direct ES, is in the range of 6.5 to $10.7 \mathrm{~mm}$ (25). The same authors found an error in the identification of motor areas and the use of neuronavigation procedures ranging from 1.5 to $4 \mathrm{~mm}$, with an additional $5 \mathrm{~mm}$ by craniotomy and opening the dura mater due to brain shift and highlighting $\operatorname{CSF}(4,9)$. Our results and review of the literature impose direct electrostimulation as binding intraoperative procedure for all lesions localized in the region of the motor cortex.

\section{REFERENCES}

1. Ammirati M, Vick N, Liao Y, Ciric l, Mikhael M: Effect of the extent of surgical resection on survival and quality of life in patients with supratentorial glioblastomas and anaplastic astrocytomas. Neurosurgery 21:201-206, 1987

2. Berger MS, Ojemann GA: Intraoperative brain mapping techniques in neuro- oncology. Stereotact Funct Neurosurg 58: 153-161, 1992

3. Cushing $\mathrm{H}$ : A note upon the faradic stimulation of central gyrus in conscious patients. Brain 32: 42-53, 1909

4. Danks RA, Aglio LS, Gugino LD, Black PM: Craniotomy under local anesthesia and monitored conscious sedation for the resection of tumors involving eloquent cortex. J Neurooncol 49:131-139, 2000

5. Duffau $H$, Capelle L, Sichez JP, Faillot $T$, Abdennour L, Law Koune JD, Dadoun S, Bitar A, Arthuis F, Van Effenterre R, Fohanno D: Intraoperative direct electrical stimulations of the central nervous system: The Salpêtrière experience with 60 patients. Acta Neurochir (Wien) 141:1157-1167, 1999

6. Duffau $\mathrm{H}$, Siches JP, Lechericy S: Intraoperative unmasking of brain redundant motor sites during resection of a precentral angioma. Evidence using direct cortical stimulations. Ann Neurol 47:132-135, 2000

7. Duffau H, Capelle L, Sichez N, Denvil D, Lopes M, Sichez JP, Bitar A, Fohanno D: Intraoperative mapping of the subcortical language pathways using direct stimulations. An anatomofunctional study. Brain 125:199-214, 2002

8. Duffau H, Denvil D, Lopes M, Gasparini F, Cohen L, Capelle $L$, van Effenterre R: Intraoperative mapping of the cortical areas involved in multiplication and subtraction: An electrostimulation study in a patient with a left parietal glioma. J Neurol Neurosurg Psychiatry 73: 733-738, 2002

9. Dorward NL, Alberti O, Velani B, Gerritsen FA, Harkness WF, Kitchen ND, Thomas DG: Postimaging brain distortion: Magnitude, correlates, and impact on neuronavigation. J Neurosurg 88:656-662, 1998
10. Gruenbaum ASF, Sherrington C: Observations on physiology of the cerebral cortex of some of the higher apes. Proc R Soc Lond B Biol Sci 72: 152-209, 1903

11. Horsley V: The Croonian Lecture: On the mammalian nervous system, its functions and their localization, determined by an electrical method. Philos Trans R Soc Lond B Biol 182: 267326,1891

12. Horsley V, Schäfer EA: I. A. record of experiments upon the functions of the cerebral cortex. Philos Trans R Soc Lond B Biol 179: 1-45, 1888

13. Levin VA, Sheline PH, Gutin PH: Neoplasms of central nervous system, in de Vita, Helman VTS, Rosenberg SA (eds): Cancer. Principles and Practice of Onkology, vol 2, 3rd ed. Philadelphia: Lippincott, 1989:1557-1612

14. Louis $\mathrm{D}$, Ohgaki $\mathrm{H}$, Wiestler $\mathrm{O}$, et al: WHO classification of tumors of the central nervous system. Lyon: IARC Press, 2007

15. Kubben PL, Postma AA, Kessels AG, van Overbeeke JJ, van Santbrink H: Intraobserver and interobserver agreement in volumetric assessment of glioblastoma multiforme resection. Neurosurgery 67(5): 1329-1334, 2010

16. Meyer FB, Bates LM, Goerss SJ, Friedman JA, Windschitl WL, Duffy JR, Perkins WJ, O'Neill BP: Awake craniotomy for aggressive resection of primary gliomas located in eloquent brain. Mayo Clin Proc 76:677-687, 2001

17. Mohin G, Madajewicz S, Manzione J, Franceschib D: Glioblastoma multiforme: Advances in postsurgical management. Commun Oncol 3: 678-684, 2006

18. Ojemann G, Ojemann J, Lettich E, Berger M: Cortical language localization in left, dominant hemisphere; An electrical stimulation mapping investigatton in 117 patients. J Neurosurg 71: 316-326, 1989

19. Ojemann JG, Miller JW, Silbergeld DL: Preserved function in brain invaded by tumor. Neurosurgery 39: 253-259, 1996

20. Penfield W, Boldrey E: Somatic motor and sensory representation in the cerebral cortex of man as studied by electrical stimulation. Brain 60: 389-443, 1937

21. Sala F, Lanteri P: Brain surgery in motor areas: The invaluable assistance of intraoperative neurophysiological monitoring. J Neurosurg Sci 47: 79-88, 2003

22. Salcman M: Epidemilogy and factors affecting survival, in Apuzzo MLJ, (ed). Malignant Cerebral Gliomas. Neurosurgical Topics. Illinois: Park Ridge, 1990:95-110

23. Sanai N, Berger MS: Glioma extent of resection and its impact on patient outcome. Neurosurgery 62(4): 753-764, 2008

24. Schiffbauer H, Ferrari P, Rowley HA, Berger MS, Roberts TP: Functional activity within brain tumors: A magnetic source imaging study. Neurosurgery 49: 1313-1320, 2001

25. Schiffbauer $H$, Berger MS, Ferrari P, Freudenstein D, Rowley HA, Roberts TP: Preoperative magnetic source imaging for brain tumor surgery: A quantitative comparison with intraoperative sensory and motor mapping. Neurosurg Focus 15(1):1-10, 2003

26. Shinoda J, Sakai N, Murase S, Yano H, Matsuhisa T, Funakoshi T: Selection of eligible patients with supratentorialglioblastoma multiforme for gross total resection. J Neurooncol 52: 161171,2001 
27. Skirboll SS, Ojemann GA, Berger MS, Lettich E, Winn HR: Functional cortex and subcortical white matter located within gliomas. Neurosurgery 38: 678-684, 1996

28. Saksena S, Jain R, Narang J, Scarpace L, Schultz LR, Lehman NL, Hearshen D, Patel SC, Mikkelsen T: Predicting survival in glioblastomas using diffusion tensor imaging metrics. Journal of Magnetic Resonance Imaging 32:788-759, 2010

29. Suess O, Suess $S$, Brock $M$, Kombos $T$ : Intraoperative electrocortical stimulation of Brodman area 4: A 10-year analysis of 255 cases. Head Face Med 2:20, 2006

30. Swanson KR, Alvord EC Jr, Murray JD: Virtual brain tumors (gliomas) enhance the reality of medical imaging and highlight inadequacies of current therapy. $\mathrm{Br} J$ Cancer 86: 14-18, 2002
31. Taylor MD, Bernstein M: Awake craniotomy with brain mapping as a routine surgical approach to treating patients with supratentorial intraaxial tumors: A prospective trial of 200 cases. J Neurosurg 90: 35-41, 1999

32. Thiel A, Herholz K, Koyuncu A, Ghaemi M, Kracht LW, Habedank B, Heiss WD: Plasticity of language networks in patients with brain tumors: A positron emission tomography activation study. P Ann Neurol 50:620-629, 2001

33. Uematsu S, Lesser RP, Gordon B: Localization of sensorimotor cortex: The influence of Sherrington and Cushing on the modern concept. Neurosurgery 30:904-913, 1992

34. Yoshiura T, Hasuo K, Mihara F, Masuda K, Morioka T, Fukui $M$ : Increased activity of the ipsilateral motor cortex during a hand motor task in patients with brain tumor and paresis. Am J Neuroradiol 18:865-869, 1997 